This is an electronic reprint of the original article. This reprint may differ from the original in pagination and typographic detail.

Author(s): Onkila, Tiina; Joensuu, Kristiina; Koskela, Marileena

Title: Implications of Managerial Framing of Stakeholders in Environmental Reports

Year: $\quad 2014$

Version:

Please cite the original version:

Onkila, T., Joensuu, K., \& Koskela, M. (2014). Implications of Managerial Framing of Stakeholders in Environmental Reports. Social and Environmental Accountability Journal, 34(3), 134-156. https://doi.org/10.1080/0969160X.2013.870488

All material supplied via JYX is protected by copyright and other intellectual property rights, and duplication or sale of all or part of any of the repository collections is not permitted, except that material may be duplicated by you for your research use or educational purposes in electronic or print form. You must obtain permission for any other use. Electronic or print copies may not be offered, whether for sale or otherwise to anyone who is not an authorised user. 


\section{IMPLICATIONS OF MANAGERIAL FRAMING OF}

\section{STAKEHOLDERS IN ENVIRONMENTAL REPORTS}

\section{ABSTRACT}

Corporate environmental reports are increasingly viewed as products of the managerial framing of responsibility and stakeholders. This notion encouraged us to conduct a multiple- case study on how stakeholders are framed in environmental reports. We show how interaction between companies and stakeholders is described in the environmental reports of three firms operating in different business sectors - financial, aviation, and energy - over a period of five years. We use an inductively oriented content analysis to identify five categories of relationships being constructed in the data: demanding, promoting, committing, donating, and preventing. We then show how commitment and promotion dominate. We conclude by discussing the implications of this type of managerial framing to maintaining business-as-usual approaches to corporate environmentalism and show how the critique of environmental reports derives from stakeholder accountability and critical approaches. We argue that managerial framing of stakeholders in environmental reports partly explains the increased criticism among stakeholder representatives and academics.

Keywords: environmental report, stakeholder, business sector, multiple case study 


\section{INTRODUCTION}

Researchers place stakeholder interaction at the core of tackling the challenge of sustainability in business. Environmental sustainability is said to require societal actors to interact, to make choices, and to resolve different perspectives on issues, options, and outcomes (Roome and Wijen, 2006) and to empower and engage different stakeholders (Bansal, 2002; Fraser et al., 2006). Indeed, the previous literature on business environmentalism has been dominated by stakeholder approaches (Roome and Wijen, 2006; Sharma and Henriques, 2005; Delmas and Toffel, 2008), but how is this reflected in corporate environmental reports?

Prior research has proved the existence of stakeholder demands for business environmentalism (Sharma and Henriques, 2005; Elijido-Ten et al., 2010, Henriques and Sadorsky, 1999; Delmas and Toffel, 2008; Gonzalez-Benito and Gonzalez-Benito, 2010, Sharma and Henriques, 2005). More specifically, stakeholder demands for environmental reporting in particular have been identified (Elijido-Ten et al., 2010; O’Dwyer et al., 2005a). Reporting typically uses stakeholder-oriented language, but it is critical to know who are being mentioned as stakeholders and how. Environmental reporting is increasingly criticized, especially regarding the extent to which it serves stakeholder dialogue (Adams, 2002; Adams, 2004; O'Dwyer et $a l ., 2005 b)$ and for the dominance of the managerial focus (Brown and Dillard, 2013; Spence, 2007; Archel et al., 2011; Dey, 2003; Brown and Fraser, 2006). Thus prior research offers us a contradiction to study further: while extensive literature has proved the existence of stakeholders' environmental demands, environmental reports are dominated by managerial approaches instead of identifying and responding to stakeholders' environmental demands. We 
explore this notion further as we study how stakeholders are framed in environmental reports of three Finnish firms between 2007 and 2011. Findings on the influence of different business sectors on corporate environmentalism (Banerjee et al., 2003; Gonzalez-Benito and GonzalezBenito, 2010) and especially on environmental reporting (Adams, 2002) led us to collect data from a range of business sectors (aviation, financing and energy) with varying backgrounds from the viewpoint of environmental demands. To determine how stakeholders were framed in the reports, we conducted content analysis to quantify the content and to identify qualitative similarities and differences in the data.

Our findings contribute to the discussion of managerial framing of stakeholders in environmental reporting (Manetti, 2011; Brown and Dillard, 2006) by showing how stakeholders are framed in environmental reports and the dominance of managerial framing of stakeholders. We discuss the implicationsof this type of framing for maintaining business as usual and increasing criticism of the reports.

Our paper is structured as follows: first we shortly review the literature on stakeholder environmental demands and business sector differences. We then use Brown and Dillard's (2006) categorization of approaches to social and environmental reports to discuss managerial, stakeholder accountability and critical approaches to environmental reporting. We continue by presenting the research contexts, material and analysis. We then discuss the findings of different stakeholder frames in the studied reports. We finally draw conclusions and discuss the implications of managerial framing of stakeholders in environmental reports. 


\section{STAKEHOLDER DEMANDS AND ENVIRONMENTAL REPORTS}

\subsection{Stakeholders' environmental demands}

By "stakeholder", we refer here to those actors with whom the company has two-way interaction or an exchange of influence, following Freeman (1984) and Carroll (1993). Carroll (1993) divided stakeholders into primary and secondary groups. Primary stakeholders have a formal, official or contractual relationship with the firm. All other groups are classified as secondary stakeholders. The recent literature has, however, criticised these definitions for excluding the natural environment from the list of stakeholders, and some authors have advanced the status of the environment as a stakeholder (see Driscoll and Starik, 2004; Carroll, 1993; Stead and Stead, 1996; Madsen and Ulhoi, 2001; Haigh and Griffiths, 2009; Onkila, 2011). In this study, we do not include the environment itself as a stakeholder. Instead we decided to focus on human stakeholders for the clarity of the analysis and comparability with the previous research.

Descriptive (cf. Donaldson and Preston, 1995) applications of stakeholder theory in environmental management have made two important contributions: they have shown the existence of multiple and conflicting stakeholder demands for corporate environmental management, and they have revealed the business sector differences in stakeholder demands.

First, several stakeholder groups have been noted as being concerned with environmental matters, albeit for different reasons (Plaza-Ubeda et al., 2009). Prior research has identified the environmental demands set by multiple stakeholders which have influenced the 
environmental practices adopted by firms. Henriques and Sadorsky (1999) identified four groups that managers perceive as setting environmental demands: regulatory stakeholders (government and trade associations), organizational stakeholders (customers, suppliers, employees and shareholders), community stakeholders (community groups and environmental organizations) and the media. This list of stakeholders has since been supported by many other studies examining environmental demands from different stakeholder groups (Banerjee and Bonnefous, 2011; Sharma and Henriques, 2005; Delmas and Toffel, 2004): Banerjee and Bonnefous (2011) identified different strategies for addressing supportive stakeholders (such as government and international institutions), obstructive stakeholders (NGOs) and passive stakeholders (the general public). Sharma and Henriques (2005) identified the multiplicity of withholding influences (by regulators and environmental NGOs), usage influences (by customers) and employee influences (through involvement) were identified by managers. In addition to these influences, others were identified from internal, regulatory and supply-chain sources by Darnall et al. (2009), whereas Bremmers et al. (2007) found that primary stakeholders (such as the government and customers) are more relevant than secondary stakeholders such as environmental organisations. Delmas and Toffel (2004) identified customers, regulators, legislators, local communities and environmental activist organizations as influential stakeholders. Murillo-Luna et al. (2006) identified that managers attach the greatest importance to two groups -regulatory stakeholders and corporate government stakeholders - but that they also perceive pressure from external economic stakeholders, internal economic stakeholders and external social stakeholders. Sprengel and Busch (2011) found that three stakeholder groups were perceived to consistently exert the highest pressure on corporate environmental strategies: governments, NGOs and the media / general public. In addition, previous research has identified that less powerful stakeholders exert influence through more powerful ones (Henriques and Sharma, 2005). 
As many different stakeholder demands have been identified, research has also shown the differences in corporate responses to those demands (Gonzalez-Benito and Gonzalez-Benito 2010; Delmas and Toffel, 2004). However, Murillo-Luna et al. (2008) noticed when a firm responds to an environmental demand, it is responding to all groups. In other words, firms do not respond selectively to the different stakeholder groups, but they respond to all of them in a similar way. Sprengel and Busch's (2011) findings support the conclusion of Murillo-Luna et al. (2008) that the corporate response strategy does not reflect the different sources of perceived stakeholder pressure.

Second, researchers have highlighted the importance of the business sector for environmental demands. Researchers have noticed variations of stakeholder influence on EMS development (Bremmers et al., 2007) and they have shown industry-based differences in managerial perceptions of corporate environmentalism. Accordingly, they have concluded that industries with high environmental impact have significantly greater levels of environmental orientation and strategy focus (Banerjee et al., 2003). Supporting these findings, the work of GonzalezBenito and Gonzalez-Benito (2010) revealed that those sectors with significant actual or potential impact on the natural environment (i.e. significant environmental impact and risk) receive greater stakeholder environmental demands. Especially industry groups have been seen to have an influence on reporting practices (Adams, 2002).

In sum, previous literature has identified multiple stakeholder groups that set environmental demands for companies and differences in business responses on different business sector. The stakeholders commonly mentioned in these studies are the government and regulators, customers, suppliers, employees, shareholders, community or the general public, 
environmental NGOs and the media. Thus, the approaches follow Henriques and Sadorsky's (1999) classification of regulatory stakeholders, organisational stakeholders, community stakeholders and the media. At the same time, the identified stakeholder groups include both the primary and secondary stakeholders classified by Carroll (1993).

\subsection{Stakeholders in environmental reporting}

Prior literature has addressed increasing calls for stakeholder communication and participation in corporate environmental management (Madsen and Ulhoi, 2001; Van Marrewijk, 2003; Reed, 2008; Oxley Green and Hunton-Clarke, 2003; Nielsen, 2001; Morsing and Schultz, 2006). Environmental reports are now a dominant channel of corporate environmental communication. The literature has primarily treated environmental reports as channels for companies to disseminate information about relevant social and environmental issues and thus many studies have focused on the contents of the reports and businesses' definitions of their responsibility (e.g. Adams et al., 1998; Hartman et al., 2007). However, current reports are facing increasing criticism and have been characterized by the dominance of managerial approaches (Brown and Dillard, 2013; Spence, 2007; Archel et al., 2011; Dey, 2003; Brown and Fraser, 2006). Business case and managerial approaches are often used as synonyms for using reporting for business case purposes and enhancing shareholder value. Here we use the term "managerial" by which we refer to environmental reports as an extension of management's toolkit for shareholder value (Brown and Fraser, 2006).

A number of studies have indicated that companies are faced with increasing pressures from diverse stakeholder groups to address environmental concerns in their reports (Dixon et al., 
2005) and increasingly the reports are understood as a way of seeking legitimacy (see Deegan, 2002; Gray et al., 1995; Laine, 2009; Morsing and Schultz, 2006). The importance of reporting as a means of maintaining legitimacy is connected to existing stakeholder demands (ElijidoTen et al., 2010; Dixon et al., 2005) and increasing a firm's legitimacy (Hunter and Bansal, 2007). Milne and Patten (2002) state that under some circumstances, positive environmental disclosures may even restore or repair an organization's legitimacy. In addition, Morsing and Schultz (2006) cite informing audiences, making stakeholders aware of corporate CSR efforts, and establishing legitimacy as primary reasons for producing the reports

Brown and Fraser (2006) analysed three broad approaches to social and environmental accounting: business case (managerial), stakeholder accountability, and critical theory. They state that the business case (managerial) approach is currently the dominant one. This approach refers to environmental reports as an extension of management's toolkit for shareholder value. According to stakeholder accountability, environmental reports should increase stakeholder accountability and transparency. Critical theory approach highlights that the reports should expose basic contradictions and environmental degradation. Brown and Fraser's analysis is summarized from the perspective of environmental reports in Table 1. 
In this study we use the term "managerial frame" to describe Brown and Fraser's business case frame. We believe that "managerial frame" is a more descriptive concept in a stakeholder oriented study since it expresses clearly the focus in the frame concerning stakeholders: it is focused on the management of stakeholders instead of e.g. stakeholder accountability (Brown and Fraser, 2006).

By managerial perspective they refer to viewing social and environmental reporting from its benefit to business and shareholders. Managerial frame proponents tend to ignore, deny or gloss over conflicts of in interest in business society relationships (O'Dwyer, 2003). In this view environmental reporting is also recognized as a way of managing threats to organizational legitimacy and used by companies for demonstrating their positive impact on society. Social and environmental accounting involves consulting with stakeholders.

This (Brown and Fraser, 2006) approach to framing stakeholders has been the major source of criticism for environmental reports. Researchers have observed the presence of managerial social and environmental reporting motivations (Spence, 2007) and the managerial nature of the language used (Archer et al., 2011; Dey, 2003; Owen, 2008). Archer (2011) points out the managerial nature of CSR language, because it simultaneously aims to increase shareholder value while thwarting an attempt by civil society to redefine corporate power (Archel et al., 2011). Dey (2003) argues that based on the evidence of current corporate social reporting practices, it is often managers and shareholders who stand to gain the most and reports are criticized for their managerialism. Owen (2008) states that the managerial focus has dominated research approaches as well. The particular emphasis has been on studies investigating organizational determinants and managerial motivations underpinning reporting initiatives. Furthermore, Manetti (2011) studied stakeholder engagement in sustainability reporting and 
showed that in a clear majority of cases they express a stakeholder management approach rather than a stakeholder engagement approach. In the majority of the cases, stakeholder engagement objectives were to promote a positive company image. The principal aim in engaging stakeholders was to involve stakeholders in company management in order to mitigate their requests, but without delegating any decisional power to them.

The stakeholder accountability approach (Brown and Fraser, 2006) assumes that various stakeholders have rights to information which must be acknowledged for decision-making purposes and to protect against potential abuses of corporate power. The potential for conflicts of interest are assumed. Stakeholder accountability theorists criticize SER for its poor quality. According to this view, stakeholders must meaningfully participate in organizational decisions and reporting.

From the stakeholder accountability perspective, prior studies have identified various stakeholder groups setting demands for environmental reports (Spence, 2009; Huang and Kung, 2010; O’Dwyer et al., 2005). Spence (2009) identified investors and employees as overwhelmingly being the most important audiences targeted by social and environmental reporting managers, whereas Huang and Kung (2010) found three groups of stakeholders that greatly influence managerial choices of environmental disclosure strategies: external stakeholders (government, debtors, consumers), internal stakeholders (shareholders, employees) and intermediate stakeholders (environmental NGOs and accounting firms). They also showed that the level of environmental disclosures is significantly affected by demands of stakeholder groups. A study by O'Dwyer et al. (2005a) presented evidence of a widespread demand for mandated and externally verified sustainability reporting from social and environmental NGOs. This demand is primarily driven by the desire to gain knowledge of 
companies' commitment to responsible business practices, but it is also influenced, albeit to a lesser extent, by the perceived ability of sustainability reporting to put increased NGO pressure on companies. Furthermore, Deegan and Blomquist (2006) reported on the positive contribution of NGO initiatives in improving the quality of environmental reporting. In addition, previous research has identified differences in environmental reporting for different stakeholders. Sotorrio and Sanchez (2010) noticed reporting being more complete for worldwide stakeholders than for domestic ones. They also found that there are no significant differences in the types of information reported, as it is most commonly general information concerning corporate policies, goals and actions. In addition, Brown and Deegan (1998) found a positive association between levels of environmental disclosure and media coverage of various industries' environmental aspects.

However, the lack of stakeholder accountability has been a major source of criticism of environmental reporting. It has been questioned to what extent social and environmental reporting serves as a means of engaging in dialogue with stakeholders (Spence, 2009; Perrini and Tencati, 2006). Spence (2009) argues that reporting serves mainly as a vehicle that organizations can use to communicate with themselves, because he noticed that managers responsible for social and environmental reporting experienced investors and employees to be their most important target audiences. The criticism also stresses the need for increased transparency. Huang and Kung (2010) state that firms which provide transparent environmental disclosure satisfy the demands of different stakeholders groups. Adams (2002) raised an important point about the relationship between reporting and stakeholder dialogue: to ensure the completeness of reporting, there should be a two-way dialogue with stakeholders. Because examples of dialogue were missing in her data, it is difficult to see how reports can ever reflect all issues of importance to key stakeholder groups if there is no dialogue. Adams (2004) 
highlights the need for stakeholder interaction as the basis for environmental reports: the different goals of companies and their stakeholders mean that reports cannot be complete unless stakeholders are consulted. Instead, companies have been perceived as resistant to stakeholder interaction in reporting or complete and credible corporate social disclosure (O'Dwyer et al., 2005b). Dixon et al. (2005) suggest more standardized ways of reporting to ensure adoption of the generally accepted rules and principles concerning reporting, including stakeholder involvement in the companies' policies towards environmental matters.

Furthermore, problems with reporting practices have included, for instance, failure to report environmental costs and lack of transparency (Raiborn et al., 2011), lack of standardized practices (Dixon et al., 2005), and lack of credibility and sufficiency (O'Dwyer et al., 2005a; Tilt, 1994) and lack of accountability (Cooper and Owen, 2007). More specifically, O'Dwyer et al. (2005a) showed that current sustainability reports are viewed negatively with regard to their credibility and sufficiency, as well as the opportunities provided for engagement, particularly among environmental NGOs. In terms of the lack of credibility of environmental reports, Cerin (2002a, 2002b) sees them more as public relations products than as effective methodologies to control and manage corporate performance. Tregidga and Milne (2006) raised concerns about how corporate environmental reporting serves to construct corporate responses to sustainable development and legitimate organizations.

The critical theory (Brown and Fraser 2006) approach is sceptical about the potential for real accountability in the absences of radical change in capitalist society. They focus on imbalances of power and resources and argue that most efforts in this area will do nothing but prop up inequitable and alienating societal structures. These theorists believe that environmental reports should focus on highlighting rather than downplaying social conflicts and struggles. 
The major source of environmental reporting criticism derived from this approach is the lack of reporting on conflicts. The aim of reports often seems to be to steer public attention into more positive directions and therefore away from actual problems; thus, people may perceive a discrepancy between reports and what the company is actually doing (Cerin, 2002b). Hedberg and von Malmborg (2003) continue by questioning the reliability of reports that focus more on showing that a company is good while omitting the negative. They discovered that CSR reports offer more help for internal stakeholders than external stakeholders. Owen et al. (2001) focused on corporate power in reporting and concluded that social and ethical reporting fails to address the crucial dimension of corporate power.

\section{MATERIAL AND METHODS}

\subsection{Multiple case study}

In this study, we followed a case study approach that is characterized by concern with the complexity and particular nature of the case in question (Stake, 1995). We applied the approach by constructing descriptions and understanding of three different cases, addressing stakeholders in the environmental reports of three different firms within the timeframe of 20072011. Our aim was to gain better understanding of this changing business practice without an intent of developing new managerial tools (see Eriksson and Kovalainen, 2008). As we focus on three cases, we call this a multiple case study (Yin, 2002), a form of research that is often undertaken for the purpose of comparing cases included in the study (Bryman and Bell, 2007). 
We found companies in the energy, aviation and financing sectors to be interesting for this study because of the different starting points they represent for this issue. There are major differences in the environmental demands met in these businesses. The ownership structure of the organisations makes them interesting for studying a business practice that is said to be dominated by the aim of shareholder value maximation (Brown and Fraser 2006). Furthermore they all have received national prizes for the good quality of their reports.

All three companies whose reporting we studied are Finnish firms. Tapiola operates in the financial sector. Its operations include banking, financing, and insurance services. As a cooperative, it is owned by its customers, so it has no need to "enhance shareholder value". Prior research has provided evidence of how these different types of ownership structures, especially local ownership, may support pursuing sustainability and challenging the "economic theory of the firm" (Stubbs and Cocklin, 2007). Tapiola clearly aims at being a pioneer in corporate responsibility in Finnish financial business and it has received national awards for its pioneering reporting efforts in the financial sector. Tapiola has had no major public conflicts about environmental issues and so has a rather neutral reputation. In other words, Tapiola has not received any significant criticism or attention for irresponsibility. Although in many cases financial companies have been excluded from reporting studies for not having severe environmental impacts (Roberts, 1991; Schadewitz and Niskala, 2010), responsibility questions related to financing have started to increase attention lately, especially due to the financial firms' power in investment decisions (Coupland, 2006; Douglas et al. 2004).

Unlike the financial company, with a neutral reputation and facing no environmental demands, both the aviation and energy firm need to meet more environmental requirements. Additionally, they are both more than $50 \%$ state owned. Finnair operates in a business sector that is facing 
significant environmental challenges at the moment (Lynes and Andrachuk, 2008), and its environmental management and reporting practices are increasingly receiving attention (Cowper-Smith and de Grosbois, 2011; Mak and Chan, 2006; Lynes and Dredge, 2006). Public awareness of aviation's environmental impacts has grown, and increasing fuel prices are pushing the aviation industry toward less fuel-consuming solutions. The biggest shareholder of the company is the State of Finland (56\% of shares), with other shareholders including insurance companies, other companies, and private individuals. Finnair has not, however, been the target of major criticism from NGOs. Finnair has received some NGO attention regarding the climate change impacts of the aviation industry (e.g. WWF). In addition, Finnair has been accused of greenwashing by Greenpeace (Valkama, 2008). On a global scale, however, the aviation industry's role in air pollution has been noted by NGOs in public discussion (e.g. Greenpeace, 2013; Friends of the Earth, 2002).

Fortum operates in the energy sector and is naturally related with heavy environmental impacts (e.g. Finnveden et al., 2003). The biggest shareholder of the company is the State of Finland (51\% of shares). Other shareholders include insurance companies, other companies, and private individuals. Fortum is continuously the target of public criticism campaigns by NGOs, especially from Greenpeace regarding the company's relation to nuclear power (see e.g. Greenpeace, 2011, 2010, 2007).

\subsection{Public environmental reports as research material}

The material for our analysis was drawn from responsibility/sustainability reports of the three firms from 2007-2011. The types of reports varied between environmental reports, sustainability reports, corporate social responsibility reports, annual reports and web-based 
annual reports (see Table 2). In each report, sections dealing with environmental issues were analysed.

Tapiola has published separate corporate social responsibility reports for 2007, 2008 and 2009. The length of these reports varies from 40 to 60 pages. In 2010, Tapiola published an annual report which was 60 pages in length. The section on responsible business was 28 pages long and included sections on environmental responsibility. In 2011, the form of reporting changed again and Tapiola published a condensed, web-based annual report which was only 33 pages long; corporate social responsibility issues, including environmental issues, were covered in only 8 pages.

Finnair has published an environmental report for 2007 and corporate social responsibility reports for 2008, 2009 and 2010. The length of the reports varies from 14 to 62 pages with environmental sections being 14-16 pages in length. In 2011, they published a sustainability report of 84 pages with a different structure: there is no separate section for environmental issues. For this research, we have analysed the environmental sections of 2007-2010 and those chapters of the 2011 report that consist of environmental information.

Fortum published a corporate social responsibility report as a part of its annual reports in 20072009. The length of these reports varied between about 60 and nearly 200 pages. The length of the CSR information in these varied from 11 to 14 pages. In 2010 and 2011, Fortum published a stand-alone corporate social responsibility report. The length of these varied between about 70 and 120 pages. 
The title and length of each studied report is described in Table 2. As we focused on analyzing the environmental sections in these reports, their length is mentioned separately.

\subsection{Content analysis}

In our data analysis, we applied the principles of content analysis both qualitatively (for identifying themes in the research material) and quantitatively (for analyzing occurrences of the identified themes in the data) (Bryman and Bell, 2007; Tuomi and Sarajärvi, 2004). Content analysis is often characterized by a concern with the content of a text and frequencies within the text (e.g. number of words and expressions) instead of meaning and structure (Eriksson and Kovalainen, 2008); it is interested in establishing categories and counting the number of instances that fall within each category (Silverman, 2006). Prior literature has noted the challenges of simply quantifying the content in accounting research (Hasseldine et al., 2005; Uberman, 1999; Steenkamp and Northcott, 2007) and this is not our aim here: instead we focus on qualifying the meanings in our categories and on quantifying those categories to show how stakeholders are framed in environmental reports. We started the logic of content analysis inductively, without theoretical assumptions steering our analysis. This is how the analysis process proceeded: first, we read through each report to identify those sections in which environmental issues were discussed. We then continued the analysis with the help of the ATLAS.ti qualitative analysis program. We were interested in the meanings given to stakeholders in relation to environmental responsibility in the reports. In dialogue with the reports, we created the following question to support our coding process (and to identify 
stakeholder frames). To find the different meanings, we coded each section discussing environmental issues according to the following questions:

- Which stakeholder is mentioned?

- Who is described as acting (e.g. company, stakeholder or a cooperation between these)?

- What action is described?

- What is described as the target of the action (referring to different types of issues)?

The reliability of the coding was confirmed by constant interaction between the researchers. We first agreed on the principles of coding. Then we checked all the unclear sections and made the final coding decisions jointly. We then analysed the coded sentences according to differences and similarities in descriptions and based on those formed five different frames for stakeholders in environmental reports: promotion, commitment, demanding, donating and preventing. We compared our findings with Brown and Fraser's (2006) categories of business case, stakeholder accountability and critical perspectives and observed that managerial frame dominates the reports.

We analysed a total of 510 descriptions of stakeholder interaction in the reports. We identified ten main stakeholder groups mentioned in the reports: customers, suppliers and business partners, employees, local community and society, the business sector, authorities, international guidelines, NGOs, external auditors and the media. In the reports, these stakeholder groups consist of more detailed actors (e.g. the names of NGO organizations) to general stakeholder class (authorities, NGOs, employees, etc). 


\section{RESULTS: TYPES OF STAKEHOLDER FRAMING IN ENVIRONMENTAL REPORTS}

\subsection{Different types of stakeholder frames}

Based on our analysis, we formed five frames for stakeholders in environmental reports: promotion, commitment, demanding, donating and preventing. The content of each frame is described in Table 3. The table also describes how managerial framing dominates the stakeholder frames in environmental reports and how stakeholder accountability and critical approaches are clearly a minority. Furthermore, managerial framing is expressed through many stakeholder frames: in promotion it's used to build a good reputation; in demanding and commitment and donations, it's used to construct legitimacy for corporate actions. All of these ways the frames are used refer to win-win situations and stakeholder management approaches as suggested in Brown and Fraser's (2006) managerial approach.

\section{Promotion: stakeholders as recipients of pro-environmental influence of business}

Within this frame an actor is described as promoting environmental responsibility among other actors or in society. It refers to an actor's positive contribution to environmental responsibility among other actors, using terms such as advance, advise, guide, offer and educate. Promotion is used to describe the company advancing environmental responsibility among mentioned stakeholders (e.g. by educating). When it is used in this way, this frame becomes a type of managerial framing of stakeholders in environmental reports: it focuses mainly on stakeholder management and the building of a responsible reputation for the company. These terms express 
the positive contributions the companies make. In the studied reports, these terms were used 137 times. In contrast, there were only a few expression of stakeholders' positive contribution to the organization (46 times). Also the expressions, in which the company and stakeholders were described as advancing environmentalism in society in cooperation, were dominated by expressing promotion. Promotion in cooperation with stakeholders was expressed 56 times. Thus, within promotion, stakeholders were framed in two managerial frames and in one on stakeholder accountability:

1. Managerial frame: As recipients of pro-environmental influence of business and the company is constructed as an actor with the ability and expertise needed in society to promote environmental responsibility (137 times)

2. Managerial frame: Co-contributors for pro-environmentalism in society (56 times)

3. Stakeholder accountability: Advancers of environmentalism in the company (46 times). This frame admits the existence of stakeholder influence on business.

\section{Commitment: sources of legitimacy}

Within this frame an actor is described as committing to the environmental criteria or principles set by another actor. This frame consists of terms expressing an undertaking of external definitions of environmental responsibility such as sign, participate, join, apply, and commit. It describes how the company follows criteria set by a stakeholder, in many cases an NGO. Commitment is used to describe the undertaking of external definitions of environmental responsibility (such as join and sign). The terms that express a company's commitment were used 152 times in the reports studied. However, it is notable here that the implementation of the commitment was not described in the reports. Instead, only commitment was expressed. In addition to that, companies were described as committing to cooperation with some other actors 
8 times. This frame thus becomes the second type of managerial framing of stakeholders in environmental reports: it focuses on stakeholders as sources of legitimacy. Stakeholders are framed as sources of legitimacy for corporate environmental action, for either individual or joint commitment. Finally, there were four instances where a stakeholder was mentioned as being committed to environmentalism, thus framing stakeholders as a way to reinforce corporate legitimacy.

\section{Demanding: stakeholders as executors of corporate environmental responsibility and targets} of corporate demands

Within this frame an actor is described as demanding environmental responsibility from other actors or in the society. As the main difference to the first frame, within this frame direct expressions entailing power are used: this consists of expressions such as require, set criteria, expect, assess, and audit. It refers to one actor using its power over another's environmental action, and thus it has a more negative tone than the first frame. However, it is remarkable here to notice that hardly any stakeholder demands were mentioned in the reports, although, as we discuss in chapter 2.1, prior literature on corporate environmentalism has proved the existence of multiple, different stakeholder demands. Stakeholder demands were mentioned only 32 times. Instead, companies were described as setting environmental demands for the stakeholders, but not as frequently as companies were described as promoting environmentalism. Corporate demands were expressed 38 times. Thus the stakeholders are framed in the reports not only as demanders of corporate environmental responsibility but also as executors of corporate environmental responsibility and targets of corporate demands instead of as parties setting demands for the companies. In these cases, the stakeholder frames are twofold: first, there is the managerial frame that again expresses stakeholders as sources of 
legitimacy for corporate environmental actions, since the company demands them to act. Second, there are traces of a critical stakeholder frame, because the demands of stakeholders on the company are identified.

\section{Donations: Stakeholders as targets of corporate philanthropy}

Within this frame an actor is simply described as donating money for the other actor. This frame consists of terms expressing philanthropic action and financial support. These expressions were used 25 times in the studied reports. Thus stakeholders are framed as targets of corporate philanthropy. Surprisingly, we also twice identified expressions in which a stakeholder is described as donating money to a stakeholder. In these cases both the recipient and the donor are outside of the organization. The stakeholders are managerially framed to increase corporate legitimacy by showing its positive societal contribution, in extreme cases even so far that a stakeholder donates to stakeholder.

\section{Prevention: stakeholders as hindrances to corporate environmental responsibility}

Within this frame stakeholders are described as hindering or making it more difficult to implement environmental responsibility. Preventing consists of terms expressing external restrictions of implementation (e.g. certain environmental improvements or changes). Stakeholders were described, for example, in the following ways: not wanting information on sustainability or restricting possibilities for sustainability. Thus stakeholders are framed as hindrances of corporate environmentalism. These expressions were used 10 times in the reports. This is the second stakeholder frame in which one can identify traces of critical framing 
of stakeholders, because conflicts in the promotion of environmentalism are identified. However, it is notable that the frame represents stakeholders as preventing the company's goodwill, thus putting the company in a positive light. In this sense, this frame can be interpreted as partly managerial, too.

Table 3 describes the stakeholder frames in environmental reports, their content, and managerial, stakeholder accountability or critical focus as well as their amounts in the reports and the textual examples.

\subsection{Development within the studied timeframe}

We identified changes that took place within the studied timeframe in the reporting of two of the studied organizations: Tapiola's focus changed from promotion to commitment and Finnair's focus moved from commitment to donating and finally promotion. Fortum maintained promotion and commitment to sustainability within the studied timeframe. Below we will describe these changes in detail. Not every mention in the reports is discussed here; instead we focus on the noteworthy changes in the categories.

In Tapiola's reports within the studied timeframe, there occurred a clear shift from expressing promotion of environmental responsibility to expressing commitment to external definitions of sustainability. All the reports were dominated by managerial frames for stakeholder descriptions of Tapiola's action (promotion and setting demands, which described Tapiola as a powerful actor and definer of responsibility). Stakeholder demands were very limited. 
However, the change showed a tendency towards identifying more external definitions of sustainability. Such a tendency indicates the start of a change from a managerial focus to stakeholder accountability (Brown and Fraser, 2006).

In the 2007 report, the focus was on describing how Tapiola promotes environmentalism by increasing environmental safety among customers and raises environmental consciousness among customers, employees and in society (mentioned in 20 of 42 descriptions). In addition, Tapiola was described as promoting sustainability cooperation with NGOs, society and suppliers (5/42). Commitment to international guidelines and NGO initiatives was only mentioned five times. In the 2008 report, stakeholders were mentioned 14 times. Thus the amount decreased from 42 times to only 14 times in a single year. The focus was on promoting environmental responsibility among customers and employees (4/14), demanding sustainability from suppliers and employees (4/14), and committing to international guidelines and external instructions (3/14). Moreover, two descriptions of cooperation for the sake of environmental consciousness were provided: with business sector actors (1) and an NGO (1). In the 2009 report, the amount of mentions of stakeholders increased to 38 times. Here again the focus was on describing how Tapiola promotes environmentalism by increasing environmental safety among customers, providing e-services, and education of employees (13/38). In addition were mentioned committing to international guidelines (2), business sector commitments (2), societal discussion (1) and NGO initiatives (2). Moreover, six descriptions of cooperation for the sake of environmental consciousness were provided: the business sector (1), NGOs (3), society (1) and customers (1).

In the 2010 report, the focus changed from promotion to commitment. Tapiola's undertaking of external definitions of sustainability were described most often (11/27 times) with 
commitment to environmental protection, UN principles for responsible investments, ICC business charter, Green office and climate commitment, and energy efficiency being reported. Also included in the report were Tapiola's promotion of environmental responsibility (8 times) and setting environmental demands (6 times). In addition, cooperation for financing wind power with business sector actors and environmental projects with an NGO were reported. In the 2011 report, the form of reporting changed and there was a drastic reduction of mentions of stakeholders (13 times). The trend noticed in the 2010 report continued: the descriptions were dominated by Tapiola's commitment to external definitions of sustainability (6/13) with commitments to the business sector's climate commitment, UN principles for responsible investments, ICC business charter, Green office and climate counter being reported. Tapiola's promotion of e-services was only mentioned twice.

In Finnair's reports, a clear change took place from commitment to donating and finally promotion. All the reports were, however, dominated by managerial stakeholder frames. With Finnair, we found that during the studied timeframe, Finnair's reporting concentrated on describing its commitment to standards and agreements. However, there was a shift to present other sustainability actions of the firm as well: donations were widely described in 2010, while promotion as an activity was also presented more and more in later years. Like Tapiola, Finnair comes across as a powerful actor and promoter of sustainability among its stakeholders; however, throughout the studied timeframe, a tendency towards identifying external definitions of sustainability can be identified. This tendency indicates the start of a change from managerial frame to stakeholder accountability (Brown and Fraser, 2006). 
In the 2007 report, there was a focus on describing Finnair's commitment to sustainability by reducing emissions and fulfilling the criteria of multiple international guidelines and agreements (5/16). In addition, the report described Finnair's actions of promoting sustainability among stakeholders. The main focus was on stressing possibilities offered by Finnair for its customers to reduce the environmental impacts of travelling (promoting sustainability among customers was mentioned four times). However, the report also reminds stakeholders of their own responsibility for their actions (3). In the 2008 report, the focus was on Finnair's commitments to sustainability (17/29), mainly commitments to international guidelines (9) but also suppliers and the business sector. The issues mentioned were certifications, declarations and principles, and sustainability projects. The report also described Finnair's actions in cooperation with stakeholders in promoting sustainability (3) and committing to sustainability (3). The actions described included developing practices and reporting related to the environment. In the 2009 report, the main focus of action was clearly on Finnair's commitment to sustainability by implementing environmental management systems, international guidelines, environmental permits and legislation. While Finnair remained the actor in most of the cases, other stakeholders were mentioned as actors more often than before (13/28 times): customers (4 times), the business sector ( 2 times), suppliers ( 2 times) and authorities (once). Society, suppliers and authorities were mentioned as demanding sustainability from Finnair. The issues in the report that were demanded relate to sustainability reporting and emission reductions.

In the 2010 report, emphasis shifted from commitment to donating money for NGOs. Environmental and social NGOs were the most mentioned groups (10/26 times), including WWF, Turtle Watch, The Finnish Association for Nature Conservation, and Earth, Sea \& Sky. Finnair still stressed its own commitment to sustainability and mentioned international 
guidelines (4/26), NGO environmental events such as Earth Hour (2 times), and an agreement with suppliers (1). Finnair promoted sustainability among customers (1), the business sector (1) and stakeholders in general (1). Finnair did not specify what groups they include in "stakeholders in general". Finnair mentioned customers, authorities and legislation demanding sustainability (3), but legislation (1) also prevents Finnair from achieving sustainability.

In 2011, Finnair updated its report design by changing the structure. The report no longer included a separate environmental section, and environmental issues were discussed throughout the report by themes. The style of the writing was more informal than before and environmental issues were presented more non-specifically. The focus on reporting stakeholder action also shifted from stressing Finnair's commitment to GRI, ISO14001, environmental permits, energy efficiency targets, etc. (18/81) to Finnair's promotion of sustainability among customers, suppliers, authorities, the business sector and stakeholders in general (19/81).

In Fortum's reports, there was no clear change in descriptions of the stakeholder relationship within the studied timeframe. All the reports were dominated by descriptions of Fortum's actions, especially promotion and commitment, and thus managerial stakeholder frames. Stakeholder demands were very limited, and they only started to emerge in more recent reports. This trend indicates the start of a change from managerial focus to stakeholder accountability and critical approaches (Brown and Fraser, 2006).

However, also in Fortum's case, changes show a tendency towards identifying more external definitions of sustainability. 
In the 2007 report, stakeholders were mentioned 16 times and were comprised of customers, employees, society, the business sector, international guidelines and NGOs. Fortum highlighted the ways it promotes sustainability among customers, employees and society (7/16). Also, Fortum described its commitment to different international agreements or guidelines fairly often (5/16). In 2008, mentions of stakeholders almost doubled to 28 . The mentioned stakeholders included customers, suppliers, employees, society, the business sector, international guidelines and NGOs. Also that year, the focus of Fortum's reporting was on its commitment to (10/28) and promotion of (13/28) sustainability. In the 2009 report, the amount of stakeholder mentions decreased to the level of the first report (15 mentions). The mentioned stakeholders here were only suppliers, society, the business sector and international guidelines. The reporting style also changed a bit by shifting the focus of Fortum's actions to stakeholders as well. Fortum mostly described its commitment to business sector agreements and to international guidelines (6/15). In this report, equal emphasis (3/15) was placed on Fortum's promotion of sustainability and suppliers' efforts to promote Fortum's sustainability work.

In 2010 and 2011, Fortum's report was a stand-alone corporate social responsibility report, which caused a significant change in the amount of stakeholder reporting mentions. In 2010, stakeholders were mentioned extensively (81 times), including groups of customers, suppliers, authorities, employees, society, the business sector, international guidelines, NGOs and external auditors. External auditors were only mentioned in this 2010 report. Fortum's promotion of (22/81) and commitment to (21/81) sustainability received the most focus, but other areas were mentioned as well. In the 2011 report, the amount of stakeholders mentions (46) decreased from 2010 but remained higher than the first three reports. Customers, suppliers, authorities, employees, local community and society, the business sector, international 
guidelines and NGOs were mentioned. Once more, most of the reporting related to Fortum committing to (20/46) and promoting (15/46) sustainability work.

\subsection{Comparison between companies}

Based on our analysis, we identified both similarities and some differences between the three companies in stakeholder frames in environmental reports. The amount of stakeholder frames in each company are represented in Tables $4 \mathrm{a}, 4 \mathrm{~b}$ and $4 \mathrm{c}$. Promotion and commitment dominated all the reports. Descriptions of cooperation with stakeholders or stakeholder demands were in a minority in all of the reports. A change toward identification of stakeholder demands seemed to be taking place in the latest reports of Finnair and Fortum: in the 2011 report, Fortum reported environmental demands from society and authorities four times and Finnair reported environmental demands from customers and authorities ten times. Within the studied timeframe, Tapiola instead maintained the approach of the company setting environmental demands on stakeholders. In several reports, they provided descriptions of environmental demands that they set for customers, suppliers and employees.

INSERT TABLES 4a, 4b and 4c ABOUT HERE

The reports were primarily dominated by descriptions of the companies promoting sustainability among stakeholders or committing to sustainability. However, within the studied years we found differences in changes of organizational reporting. In Tapiola's approach, the change was from promotion to expressing commitment. In addition, Tapiola was the only company that significantly reported setting environmental demands for certain stakeholder groups (primarily suppliers and employees). Fortum's reports concentrated on describing the 
company as promoting environmental sustainability among stakeholders and committing to environmental sustainability. Within the studied timeframe, no remarkable changes happened. Finnair's approach was first dominated by descriptions of its commitment to stakeholder-based approaches to sustainability, but in the 2010 report the focus changed to donations. Finally, in the last report studied, the company was prominently described as promoting environmental sustainability among stakeholders.

\section{CONCLUSIONS}

In line with previous authors, our study indicates that the dominant ways of framing stakeholders in environmental reports are managerially oriented. We extend on these frames by further categorizing the frames used in managerial stakeholder framing. We identified five types of frames for stakeholders in environmental reports: promoting, commitment, donating, demanding, and preventing. The dominant ways of managerial framing are promotion and commitment, through which stakeholders are primarily framed as sources of legitimacy and as ways for companies to demonstrate the companies' positive impact on society (cf. Brown and Fraser, 2006). Furthermore, stakeholders are not identified as setting environmental demands for companies, but in this type of managerial framing they are typically seen as recipients or targets of corporate pro-environmental influence. However, prior research has shown a variety of stakeholder demands on corporate environmental practices (Gonzalez-Benito and GonzalezBenito, 2010; Delmas and Toffel, 2004; Delmas and Toffel, 2008; Henriques and Sadorsky, 1999; Henriques and Sharma, 2005) and especially on environmental reports (Dixon et al., 2005; Elijido-Ten et al., 2010; Morsing and Schultz, 2006). 
We suggest that this type of managerial framing of stakeholders leads to three considerable implications: maintaining business as usual, similarities between reporting in different firms and explanations for increasing criticism of environmental reporting.

First, environmental reports seem to express no radical changes but rather focus on maintaining business as usual. This claim is supported by two of our findings: there were no remarkable changes in the ways stakeholders were framed during the studied period and the aim in the reports was to construct a powerful position for the company in promoting environmentalism among stakeholders. Furthermore, conflicts were not reported. All of this leads to a promotion of corporate power, not stakeholder influence. Thus this implication highlights the need for change in the focus on environmental reports: instead of stressing the positive contribution to society, the companies could report on changes that were actually implemented and explain the disagreement concerning their environmental decisions and how the situation was solved. Such a shift means that companies we would move towards the critical theory approach (Brown and Fraser, 2006), which would mean reporting conflict situations and highlighting radical changes.

Second, the results of the study showed that environmental reports shared a similar dominance of framing stakeholders through promotion and commitment, although the companies studied operate in very different business sectors, are of very different ownership structure and meet very different environmental demands. Previous literature has confirmed differences in the environmental demands of separate business sectors (Banerjee et al., 2003; Gonzalez-Benito and Gonzalez-Benito, 2010). Furthermore, the ownership structure of Tapiola is that of a cooperative. It is owned by its customers, and therefore it has no need to "satisfy shareholder interests". However, Tapiola's reports are also dominated by managerial stakeholder frames. In addition, Fortum and Finnair are to a great extent owned by the state of Finland. Thus, we 
conclude that the managerial framing of stakeholders has become institutionalized in the language used in reporting and leads to similarities in the reporting practice of very different companies. Environmental practices seem to cross boundaries of business sectors and ownership structures. However, the environmental issues faced in different business sectors vary significantly. The question now becomes if the goal should be context and case-specific reporting practices rather than standardized ones (Dixon et al., 2005).

Third, we argue that this type of managerial stakeholder framing partially explains the increasing criticism of environmental reports, especially those derived from the stakeholder accountability approach (Brown and Fraser, 2006). As we have previously noted, the value of environmental reports in stakeholder dialogue has been questioned (Spence, 2009; O'Dwyer et $a l .$, 2005a). Based on our results, we call for a rethinking of the content of environmental reports from the stakeholder perspective. As the reports are dominated by framing stakeholders as recipients of pro-environmental contribution (promotion) and as sources of legitimacy (commitment), we believe that this is one of the main reasons that criticism of reports is increasing. If this approach continues to dominate, further criticism will result. We must ask if these companies are generally accepted in society as promoters of sustainability.

Our worry is that environmental reports, at least as they were found in our research material, require significant corporate resources but there is very little use for the reports among stakeholders. Therefore, based on our results, we suggest that corporate managers, especially the ones responsible for environmental reports, consider the following questions when starting to plan their future environmental reports (or the whole reporting process):

- For whom are they writing the report? 
- What types of environmental expectations might these groups have concerning environmental management (both explicit and implicit)?

- With whom have they had conflicts? How can we show concrete improvement and changes concerning their expectations?

Based on these questions, we would encourage them to aim at more issue- and stakeholderspecific reports (with identification of stakeholder demands, actions taken by the company, and so on explicitly mentioned in the report) instead of the more general, institutionalized form of reporting. This style of environmental reporting would call for stakeholder participation in planning and writing the report, and it might lead to more convincing and useful ways of reporting than merely expending resources.

Our study is limited in two ways. First, we only studied three Finnish companies from three business sectors. Second, we only studied the content of the environmental reports, not the perceptions of different stakeholder groups in relation to the environmental reports. As we deal with questions of addressing stakeholders in environmental reporting from the viewpoint of stakeholder engagement, it would be especially important for future studies to focus on stakeholder perceptions of environmental reports, and thus to collect qualitative interview data or focus group studies about their views on specific cases. This, we believe, would also lead to improvements in environmental reporting practices and increased applicability of the information reported. In addition, we would suggest applying this type of study to the content of environmental reporting in other countries in order to learn whether the same problems are faced in different cultures. 


\section{REFERENCES}

Adams, CA. 2002. Internal organizational factors influencing corporate social and ethical reporting. Beyond current theorizing. Accounting, Auditing \& Accountability Journal, 15 (2): 223-250.

Adams, CA. 2004. The ethical, social and environmental reporting - performance portrayal gap. Accounting, Auditing \& Accountability Journal 17 (5): 731-757.

Adams, CA., Wan-Ying, H. and Roberts, CB. 1998. Corporate social reporting practices in Western Europe: Legitimating corporate behaviour? The British Accounting Review 30:1-21.

Archel, P., Husillos, J. and Spence, C. 2011. The institutionalisation of unaccountability: Loading the dice of corporate social responsibility discourse. Accounting, organizations and society $36: 327-343$.

Banerjee, B., Iyer, E. and Kashyap, R. 2003. Corporate environmentalism: Antecedents and influence of industry type. Journal of Marketing 67:. 106-122.

Banerjee, B. and Bonnefous, A-M. 2011. Stakeholder management and sustainability strategies in the French nuclear industry. Business Strategy and the Environment 20:124-140.

Bansal, P. 2002. The corporate challenges of sustainable development. The Academy of Management Executive16 (2): 122-131. 
Bremmers, H., Omta, O., Kemp, R. and Haverkamp, D-J. 2007. Do Stakeholder Groups Influence Environmental Management System Development in the Dutch Agri-Food Sector? Business Strategy and the Environment 16: 214-231.

Brown, N. and Deegan, C. 1998. The public disclosure of environmental performance information - a dual test of media agenda setting the theory and legitimacy theory. Accounting and Business Research 29 (1): 21-41.

Brown, J. and Fraser, M. 2006. Approaches and perspectives in social and environmental accounting: and overview of the conceptual landscape. Business strategy and the Environment 15: 103-117.

Brown, J. and Dillard, J. 2013. Agonizing over engagement: SEA and the "death of environmentalism" debates. Critical perspectives on Accounting 24: 1-18.

Bryman, A. and Bell, E. 2007. Business research methods. $2^{\text {nd }}$ ed. Oxford University Press, United States.

Carroll, AB. 1993. Business and Society: Ethics and Stakeholder Management. SouthWestern Publishing Co, Cincinnati.

Cerin, P. 2002a. Characteristics of environmental reporters on the OM Stockholm exchange. Business Strategy and the Environment, 11: 298-311. 
Cerin, P. 2002b. Communication in corporate environmental reports. Corporate Social Responsibility and Environmental Management 9:46-66.

Cooper, S. and Owen, D. 2007. Corporate social reporting and stakeholder accountability: The missing link. Accounting, Organizations and Society 32: 649-667.

Coupland, C. 2006. Corporate social and environmental responsibility in web-based reports:Currency in the banking sector? Critical Perspectives on Accounting 17: 865-881.

Cowper-Smith, A. and de Grosbois, D. 2011. Theadoption of corporatesocial responsibility practices in the airline industry. Journal of Sustainable Tourism 19 (1): 59-77.

Darnall, N., Seol, I. and Sarkis, J. 2009. Perceived stakeholder influences and organizations' use of environmental audits. Accounting, Organizations and Society 34: 170-187.

Deegan, C. 2002. Introduction: The legitimatising effect of social and environmental disclosures - a theoretical foundation. Accounting, Auditing \& Accountability Journal 15 (3): $282-311$

Deegan, C. and Blomquist, C. 2006. Stakeholder influence on corporate reporting: an exploration of the interaction between WWF-Australia and the Australian minerals industry. Accounting, organizations and society 31 : 343-372.

Delmas, M. and Toffel, M. 2004. Stakeholders and environmental management practices: an institutional framework. Business Strategy and the Environment 13: 209-222. 
Delmas, M. and Toffel, M. 2008. Organizational responses to environmental demands: opening the black box. Strategic Management Journal 29(10): 1027-1055.

Dey, C. 2003. Corporate 'silent' and 'shadow' social accounting. Social and environmental accounability journal 23 (2): 6-9.

Dixon, R., Mousa, G. and Woodhead, A. 2005. The role of environmental initiatives in encouraging companies to engage in environmental reporting. European Management Journal 23 (6): 702-716.

Donaldson, T. and Preston, L.E. 1995. The Stakeholder Theory of the Corporation: Concepts, Evidence and Implications. Academy of Management Review 20(1): 65-91

Douglas, A., Doris, J. and Johnson, B. Corporate social reporting in Irish financial institutions. The TQM Magazine 16 (6): 387-395.

Driscoll, C. and Starik, M. 2004. The Primordial Stakeholder: Advancing the Conceptual Consideration of Stakeholder Status for the Natural Environment. Journal of Business Ethics, 49:55-73.

Elijido-Ten, E., Kloot, L. and Clarkson, P. 2010. Extending the application of stakeholder influence strategies to environmental disclosures. An exploratory study form a developing country. Accounting, Auditing \& Accountability Journal 23(8): 1032-1059. 
Eriksson, P. and Kovalainen, A. 2008. Qualitative methods in business research. Sage, London.

Finnveden, G., Nilsson, M., Johansson, J., Persson, Å., Moberg, Å. and Carlsson, T. 2003. Strategic environmental assessment methodologies - applications within the energy sector. Environmental Impact Assessment Review 23: 91-123.

Fraser, E., Dougill, A., Warren, E., Reed, M. and McAlpine, P. 2006. Bottom up and top down: Analysis of participatory process for sustainability indicator identification as a pathway to community empowerment and sustainable environmental management. Journal of Environmental Management 78:114-127.

Freeman, R. 1984. Strategic Management: A Stakeholder Approach. Pitman, Massachusetts.

Friend of the Earth. 2002. Aviation and global climate change. Accessed October 4, 2013. www.foe.co.uk/resource/reports/aviation_climate_change.pdf

Gonzalez-Benito, J. and Gonzalez-Benito, O. 2010. A study of determinant factors of stakeholder environmental pressure perceived by industrial companies. Business Strategy and the Environment 19: 164-181.

Gray, R., Kouhy, R. and Lavers, S. 1995. Corporate social and environmental reporting. A review of literature and a longitudinal study of UK disclosure. Accounting, Auditing \& Accountability Journal 8(2): 47-77. 
Greenpeace. 2007. Fortum pitää ydinlainsäädäntöä pilkkanaan. Lehdistötiedote 25.4.2007. (Fortum mocks the nuclear legislation. Press release $25^{\text {th }}$ April 2007) Accessed October 4, 2013 www.greenpeace.org/finland

Greenpeace. 2010. Ydinvoima Suomessa: Fortum. (Nuclear power in Finland: Fortum) Accessed October 4, 2013 www.greenpeace.org/finland

Greenpeace. 2011. Fortumin aika kantaa vastuusta ja luopua ydinvoimasta. Lehdistötiedote 31.3.2011. (Fortum needs to bear the responsibility and give up nuclear power. Press release $31^{\text {st }}$ March 2011) Accessed October 4, 2013 www.greenpeace.org/finland

Greenpeace. 2013. The problem with aviation. Accessed October 4, 2013. Www.greenpeace.org.uk/climate/aviation

Haigh, N. and Griffiths, A. 2009. The natural environment as a primary stakeholder: the case of climate change. Business Strategy and the Environment 18: 347-359.

Hasseldine, J., Salama, A.I. and Toms, J.S. 2005. Quantity versus quality: the impact of environmental disclosures on the reputations of UK Plcs. The British accounting review 37: 231-248.

Hartman, LP., Rubin, RS. and Dhanda, KK. 2007. The communication of corporate social responsibility: United States and European Union multinational corporations. Journal of Business Ethics 74: 373-389. 
Hedberg, CJ. and Von Malmborg, F. 2003. The Global Reporting Initiative and corporate sustainability reporting in Swedish companies. Corporate Social Responsibility and Environmental Management 10:153-164.

Henriques, I. and Sadorsky, P. 1999. The Relationship between Environmental Commitment and Managerial Perceptions of Stakeholder importance. Academy of Management Journal 42:87-99.

Henriques, I. and Sharma, S. 2005. Pathways of stakeholder influence in the Canadian Forestry Industry. Business Strategy and the Environment 14: 384-398.

Huang, C. and Kung, F. 2010. Drivers of environmental disclosure and stakeholder expectation: Evidence from Taiwan. Journal of Business Ethics 96:435-451.

Hunter, T. and Bansal, P. 2007. How standard is standardized MNC global environmental communication. Journal of Business Ethics 71: 135-147.

Laine, M. 2009. Ensuring legitimacy through rhetorical changes? A longitudinal interpretation of the environmental disclosures of a leading Finnish chemical company. Accounting, Auditing \& Accountability Journal 22(7):1029-1054.

Lynes, J. and Andrachuk, M. 2008. Motivations for corporate social and environmental responsibility: A case study of Scandinavian airlines. Journal of International Management 14: 377-390. 
Lynes, J. and Dredge, D. 2006. Going green: motivations for environmental commitment in the Airline Industry. A case study of Scandinavian Airlines. Journal of sustainable tourism 14 (2): 116-138.

Madsen, H. and Ulhoi, J. 2001. Integrating Environmental and Stakeholder Management. Business Strategy and the Environment 10:77-88.

Mak, B. and Chan, W. 2006. Environmental reporting of airlines in the Asia Pacific Region. Journal of Sustainable Tourism 14 (6): 618-628.

Manetti, G. The quality of stakeholder engagement in sustainability reporting: empirical evidence and critical points. Corporate social responsibility and environmental management 18: $110-122$.

Milne, M. and Patten, D. 2002. Securing organizational legitimacy. An experimental decision case examining the impact of environmental disclosures. Accounting, Auditing \& Accountability, Journal 15(3): 372-405.

Morsing, M. and Schultz, M. 2006. Corporate social responsibility communication: stakeholder information, response and involvement strategies. Business Ethics: A European Review 15(4):323-338.

Murillo-Luna, J., Concepcion, G. and Rivera-Torres, P. 2008. Why do patterns of environmental response differ. A stakeholders' pressure approach. Strategic Management Journal 29 (11):1225-1240. 
Nielsen, B. 2001. Manuals for environmental dialogue. Corporate Environmental Strategy, 8 (3): 217-223.

O’Dwyer, B., Unerman, J. and Hession, E. 2005a. Used needs in sustainability reporting: Perspectives of stakeholders in Ireland. European Accounting Review 14 (4): 759-787.

O’Dwyer, B., Unerman, J. and Bradley, J. 2005b. Perceptions on the emergence and future development of corporate social disclosure in Ireland. Engaging the voices of nongovernmental organizations. Accounting, Auditing \& Accountability Journal 18(1): 14-43.

Onkila, T. 2011. Multiple forms of stakeholder interaction in environmental management: Business arguments regarding differences in stakeholder relationships. Business Strategy and the Environment 20 (6): 379-393.

Owen, D., Swift, T. and Hunt K. 2001. Questioning the role of stakeholder engagement in social and ethical accounting, auditing and reporting. Accounting Forum 25 (3):264-282.

Owen, D. 2008. Chronicles of wasted time? A personal reflection on the current state of, and future prospects for, social and environmental accounting research. Accounting, auditing and accountability journal 21 (2): 240-267.

Oxley Green, A. and Hunton-Clarke, L. 2003. A Typology of Stakeholder Participation for Company Environmental Decision Making. Business Strategy and the Environment 12: 292299. 
Perrini, F and Tencati, A. 2006. Sustainability and Stakeholder Management: The need for new corporate performance and reporting systems. Business Strategy and the Environment 15: 296-308.

Plaza-Ubeda, J., Burgos-Jimenez, D., Vazquez A. and Liston-Heyes, C. 2009. The "Win-Win" Paradigm and Stakeholder Integration. Business Strategy and the Environment 18(8): 487-499.

Raiborn, C., Butler J., and Massoud M. 2011. Environmental reporting: Toward enhanced information quality. Business Horizons 54:425-433.

Reed, M. 2008. Stakeholder participation for environmental management: A literature review. Biological Conservation 141: 2417-2431.

Roberts, C. 1991. Environmental disclosures: A note on reporting practices in mainland Europe. Accounting, auditing and accountability journal 4 (3): 62-71.

Roome, N. and Wijen, F. 2006. Stakeholder Power and Organisational Learning in Corporate Environmental Management. Organization Studies 27 (2): 235-263.

Schadewitz, H. and Niskala, M. 2010. Communication via responsibility reporting and its effect on firm value in Finland. Corporate social responsibility and environmental management 17: 96-106. 
Sharma, S. and Henriques, I. 2005. Stakeholder influences on sustainability practices in the Canadian forest products industry. Strategic Management Journal 26: 159-180.

Silverman, D. 2006. Interpreting qualitative data. $3^{\text {rd }}$ ed. Alden Press, Oxford.

Sotorrio, L. and Sanchez J. 2010. Corporate social reporting for different audiences: the case of multinational corporations in Spain. Corporate Social Responsibility and Environmental Management 17: 272-283.

Spence, C. 2007. Social and environmental reporting and hegemonic discourse. Accounting, Auditing and Accountability journal 20 (6): 855-822.

Spence, C. 2009. Social and environmental reporting and the corporate ego. Business Strategy and the Environment18: 254-265.

Sprengel, D and Busch T. 2011. Stakeholder engagement and environmental strategy - the case of climate change. Business Strategy and the Environment 20: 351-364.

Stake, R. 1995. The art of case study research. Sage, Thousand Oaks, CA.

Stead, W. and Stead, J. 1996. Management for a Small Planet. Sage Publications, Thousand Oaks.

Steenkamp, N. and Northcott, D. 2007. Content analysis in accounting research: the practical challenges. Australian accounting review 17 (3): 12-25. 
Stubbs, W. and Cocklin, C. 2007. Cooperative, community-spirited and commercial: Social sustainability at Bendigo Bank. Corporate social responsibility and environmental management 14: $251-262$.

Tilt, C. 1994. The influence of external pressure groups on corporate social disclosure. Some empirical evidence. Accounting, Auditing and Accountability 7 (4): 47-72.

Tregidga, H. and Milne, M. 2006. From sustainable management to sustainable development: a longitudinal analysis of a leading New Zealand environmental reporter. Business Strategy and the Environment 15: 219-241.

Tuomi, J. and Sarajärvi, A. 2004. Laadullinen tutkimus ja sisällönanalyysi (Qualitative research and content analysis). Tammi, Helsinki.

Unerman, J. 2000. Methodological issues. Reflections on quantification in corporate social reporting content analysis. Accounting, auditing and accountability journal 13 (5): 667-680. van Marrewijk, M. 2003. Concepts and Definitions of CSR and Corporate Sustainability: Between Agency and Communion. Journal of Business Ethics 44: 95-105.

Valkama, M. 2008. Greenpeace: Saastuttavat yritykset kiillottavat imagoaan viherpesulla. (Greenpeace: Polluting companies greenwash their image) HS:fi Uutiset June 19th 2008. www.hs.fi 
WWF. WWF: Lentoliikenteen ilmastovaikutus on pelkkiä hiilidioksidipäästöjä suurempi. (WWF: The climate impact of aviation is bigger than just the carbon dioxide emissions) Accessed October 4, 2013. http://wwf.fi/jarjesto/viestinta/uutiset-ja-tiedotteet/WWF-$\underline{\text { Lentoliikenteen-ilmastovaikutus-on-pelkkia-hiilidioksidipaastoja-suurempi-206.a }}$

Yin, R. 2002. Case study research. Sage, Thousand Oaks, CA. 